\title{
Validity of Generative Learning Based Respiratory System Module to Empower Students' Analytical Thinking Skills
}

\author{
${ }^{1 \text { st }}$ Widya Prawita \\ Department of Science Education \\ Sebelas Maret University \\ Surakarta, Indonesia \\ widyaprawita@student.uns.ac.id
}

\author{
${ }^{2 n d}$ Baskoro Adi Prayitno \\ Department of Science Education \\ Sebelas Maret University \\ Surakarta, Indonesia \\ baskoro_ap@fkip.uns.ac.id
}

\author{
${ }^{3 r d}$ Sugiyarto \\ Department of Science Education \\ Sebelas Maret University \\ Surakarta, Indonesia
}

\begin{abstract}
Module is a medium that assist teachers to transfer information in learning process. Nevertheless, many activities in conventional module do not really emphasize on students' analytical thinking skill. Therefore, the module needs innovation. Generative learning-based module is a module integrated with generative learning model activity, so it is supposed to be more effective in empowering students' analytical thinking skill. This study aims to test the validation of generative learning-based module that is being developed. This study is the initial product-testing phase of the type of research and development $(\mathrm{RnD})$. Validation test in this study included construct, content, evaluation, and module readability. Data collection method used was questionnaire. The subjects of this study were education experts and practitioners. The validation results obtained the following scores: the validity score of module construct was $93.37 \%$, the validity score of module content was $87.94 \%$, the validity score of evaluation was $97.14 \%$, and the validity score of readability was $88.33 \%$. All of the scores were in "very good". Shortly, it can be concluded that generative learning-based respiratory system module is incredibly valid and worthy of being tested for its effectiveness in order to empower students' analytical thinking skill.
\end{abstract}

Keywords- Biology Module; Generative Learning; Validation; Respiratory

\section{INTRODUCTION}

One of visual-based instructional media is module. Module is a medium that assist teachers to transfer information in learning process. Module is prepared as a whole and systematical, a set of planned learning experience and arranged to assist students to acquire specific learning objectives[1]. A printed instruction unit that has one integrated theme provides the students with information needed to master and evaluate the determined knowledge and skill and is used as one of the components in curriculum[2].

However, the module used in senior high school is not yet based on the activities that help students to practice their thinking abilities. The module they used is still general and not yet specific meaning that they have not tried to use model-based module, learning approach or strategy. Teaching materials just consist of detail explanation of the materials, minimum students' activity, and problems example and practice do not really connect the materials learned with its application in daily life. The module used is not yet optimal to practice the students' analytical thinking skill.

According to Facione[3], analytical thinking skill is specifically divided into four indicators: 1) interpreting information and ideas, 2) identifying the similarity and difference of reality and information being presented, 3) drawing hypothesis, 4) elaborating the correlation among sentences or parts of a concept to draw conclusion. A research conducted by Eldes[4] defined that analytical thinking skill is possible to enhance by using the model that best suits both material characteristics and student characteristics. Based on some researches, analytical thinking skill can be drilled to students through the learning model and development of teaching materials. Tiangtong Diraksa and Phairoth Terntachatipong in their research found that learning that a learning that develops analytical thinking skills and models based on constructivist theory will cause students to be motivated to do activities[5].

The analysis result of the module teaching material in SMAN 1 Kotabumi showed that the practice of information interpretation skills was $42 \%$, the practice of identifying the similarity and difference of reality and information being presented was $69 \%$, the practice of drawing hypothesis was $13 \%$, the practice component of elaborating the correlation among sentences or parts of a concept to draw conclusion was $23 \%$. The fact that the components of this analytical thinking practices are still low shows the need for a module based on activity of analytical thinking skills practices.

Through a set of activities that actively involve students in gaining meaningful knowledge in learning process is to acquire new knowledge found by the students. During the learning process, teachers will only provide facility to students in drawing their own knowledge[6]. A meaningful learning will arise if students connect their new knowledge with their previously-known knowledge[7,8]. The lack of constructing concepts and hypotheses carried out by students in semi-conventional methods causes the practices in analytical thinking skills to not run optimally[4]. According to Ritchie and Volk1[9], one of the effective learning model to train the analytical thinking skill with the optimization of concept construct activities is Generative Learning.

Generative Learning model[10] is a functional learning model from an instruction build based on the knowledge about brain process and cognitive on understanding, knowledge gaining, attention, motivation, and transfer. 
Generative Learning model encourages students to study independently, explore the knowledge from various learning sources, focus on problems being observed, carry out an experiment to construct the concept, and apply it to daily problems or difficulties[2].

Therefore, it requires a module integrated with Generative Learning components as a teaching material that is able to be used by students independently, every time and everywhere., without any limited time, so it reduces the gap in training of students' analytical thinking skills. Generative Learning-based module is also integrated with Generative Learning activities including exploration, focus, challenge, and concept application that are potential to train students' analytical thinking skill optimally.

\section{RESEARCH METODHOLOGY}

This study belonged to Research and Development (RnD) study according to Brog and Gall (1983), which was at the initial product-testing phase[11]. The target of this study was to develop module. Validity test involved some experts with a minimum standard of S2 (master degree) and Education Practitioners. The data of this study were obtained through questionnaire arranged based on Likert Scale. The coding criteria of Likert Scale in this study was visualized on Table 1.

\begin{tabular}{|c|c|}
\multicolumn{1}{c|}{ TABLE I. } & LINKERT SCALE \\
\hline Categorize & Score \\
\hline Very Low & 1 \\
\hline Low & 2 \\
\hline Good Enough & 3 \\
\hline Good & 4 \\
\hline Very Good & 5 \\
\hline
\end{tabular}

The validation result was analyzed descriptively based on the criteria of construct, content, evaluation, and readability. Validation scores obtained through Likert Scale calculation was then converted to the percentage of module feasibility. The formula to calculate the percentage of module feasibility is:

$$
K=F /(N \times I) \times 100
$$

Notes: K : Percentage, F: Amounts obtained by respondents, N: Highest score in questionnaire, I: Number of questions in questionnaire.

The module is considered feasible to use as teaching materials if the validation results reach $>62 \%$. The criteria of module feasibility can be seen on Table 2 .

TABLE II. SCORE OF INTERPRETATION MODUL CRITERIA

\begin{tabular}{|c|c|}
\hline Score & Categorize \\
\hline $83-100$ & Very good \\
\hline $62-82$ & Good \\
\hline $41-61$ & Good enough \\
\hline $0-40$ & Low \\
\hline
\end{tabular}

\section{RESULT AND DISCUSSIONS}

Based on the problems obtained during preliminary research it is concluded that one of the solutions is to develop a teaching media based on Generative Learning because it can make Biology more visible, be a solution on the lack of time in prectical activities and empower analytical thinking skills in respiratory system concept.

Generative Learning-based repiratory system module was a module designed based on a Generative Learning syntax which required the students to be actively involved during the learning process in connecting new ideas with the cognitive structure (knowledge) which the students had. It consisted of components which contained learning objectives, learning materials, learning methods, tools or media, as well as learning and evaluation resources.

\section{A. Generative Learning Based Respiratory System Module Chracteristics}

Module is developed by syntax of Generative Learning model consisted of four stage in which were exploration, focusing, challenges, and concept applications [2]. To empower analytical thinking skills of the student in the form 1) interpreting information and ideas, 2) identifying the similarities and differences of the reality from the information presented, 3) developing hypotheses, and 4) describing the relationship of sentences or parts of a concept to make decision [3] on the subjects of respiratory system concept. The forst draft of these modules includes:

\section{- Introduction}

The introduction of the module contains: 1) cover page, 2) Learning indicators, 3) Information module, 4) instructions for use module, and 5) contents module. The cover of the module can be seen on this following figure 1. Fig 1. Cover Page of the module

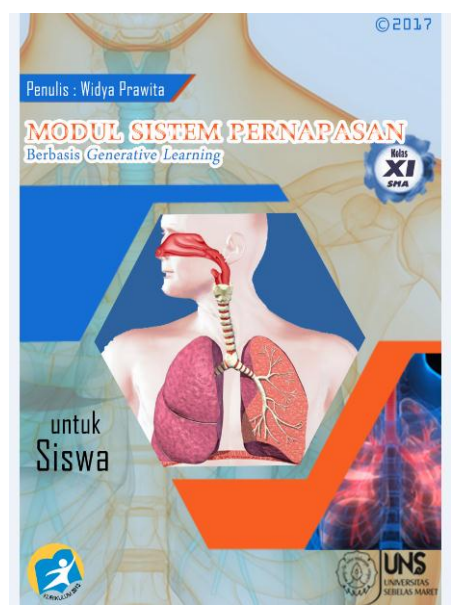

\section{- Content}

The contents are based on generative learning activities to empower analytical thinking skills. Those comprise exploration, focusing, challenges, and concept applications [2]. Each of these will be elucidated in the following subsection.

(1) Exploration

The page that belongs to exploration of brainstorming ideas provides instruction to observe the pictures accompanied by a short narrative that becomes a direction of the picture explanation. Then, it will be concluded by drawing questions related to the picture.

(2) Focusing

Part of focusing consists of some questions related to the previous step, then it leads students to argue or correct the concept owned by the students.

(3) Challenge

This part provides a space for students to strengthen the concept or correct the wrong concept through simple argumentation, then to conclude their findings.

(4) Concept Application

Concept application is an activity performed by students in solving problems presented through questions about things that usually happen by using their new concept or a concept that actually comes from their new knowledge, 
related to the practical things happened in daily life. Activities which were expected from the studentswere visualized in Table 3 .

TABLE III. THE EXPECTED OF THE GENERATIVE LEARNING SYNTAX TO ACTIVITIES IN THE MODULE

\begin{tabular}{|c|c|c|}
\hline GL Syntax & Module Activities & $\begin{array}{l}\text { Activities } \\
\text { which were } \\
\text { expected from the } \\
\text { students }\end{array}$ \\
\hline Exploration & $\begin{array}{l}\text { Students would be } \\
\text { given a stimulus in the } \\
\text { form of several } \\
\text { activities observing } \\
\text { phenomena in the form } \\
\text { of images and } \\
\text { searching a problem } \\
\text { which could show the } \\
\text { data and fact related to } \\
\text { the concepts learned. }\end{array}$ & $\begin{array}{l}\text { Observing the } \\
\text { images and then } \\
\text { making questions } \\
\text { related to the } \\
\text { images seen. }\end{array}$ \\
\hline Focusing & 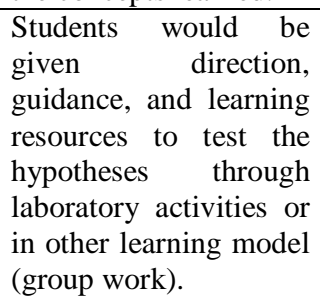 & $\begin{array}{l}\text { Conducting testing } \\
\text { activities from the } \\
\text { hypotheses through } \\
\text { laboratory } \\
\text { activities or in } \\
\text { other learning } \\
\text { model (group } \\
\text { work). }\end{array}$ \\
\hline Challenges & $\begin{array}{l}\text { Students would be } \\
\text { given worksheets so } \\
\text { that they were able to } \\
\text { conduct their practicum } \\
\text { activities appropriately. }\end{array}$ & $\begin{array}{l}\text { Conducting } \\
\text { practicum activities } \\
\text { in accordance with } \\
\text { the work } \\
\text { instruction. }\end{array}$ \\
\hline $\begin{array}{l}\text { Concept } \\
\text { Application }\end{array}$ & $\begin{array}{l}\text { Students would be } \\
\text { given essay questions } \\
\text { related to the everyday } \\
\text { life phenomena. }\end{array}$ & $\begin{array}{l}\text { Problem solving by } \\
\text { using new concepts } \\
\text { or real concepts of } \\
\text { the new knowledge }\end{array}$ \\
\hline
\end{tabular}

\section{B. Validity and Feasibility of Product}

The developed module has been validated by the validators. The validator came from three lecturers who are experts in their field. The validity of the module was assessed based on construct, content, evaluation, and readability. The details of the module validation result are presented in this following table 4.

\begin{tabular}{|c|c|c|c|}
\hline \multicolumn{2}{|r|}{ TABLE IV. } & \multicolumn{2}{|c|}{ JALIDATION RESULT BY EXPERTS } \\
\hline No & Description & $\begin{array}{c}\text { Score } \\
\text { Percentage }(\%)\end{array}$ & Categorize \\
\hline \multicolumn{4}{|c|}{ Construct } \\
\hline 1 & Arrangement & $100 \%$ & Very Good \\
\hline 2 & Suitability & $100 \%$ & Very Good \\
\hline 3 & Benefit for learning & $80 \%$ & Good \\
\hline 4 & Layout & $95 \%$ & Very Good \\
\hline 5 & Language & $88,57 \%$ & Very Good \\
\hline 6 & Generative Learning & $96,67 \%$ & Very Good \\
\hline & Average & $93,37 \%$ & Very Good \\
\hline \multicolumn{4}{|c|}{ Content } \\
\hline 1 & Relevance & $84 \%$ & Very Good \\
\hline 2 & Accuracy & $80 \%$ & Good \\
\hline 3 & Completeness & $90 \%$ & Very Good \\
\hline 4 & Basic Concepts & $85,7 \%$ & Very Good \\
\hline 5 & $\begin{array}{l}\text { Suitability in } \\
\text { generative learning }\end{array}$ & $100 \%$ & Very Good \\
\hline & Average & $87,94 \%$ & Very Good \\
\hline \multicolumn{4}{|c|}{ Evaluation } \\
\hline 1 & Subject Material & $100 \%$ & Very Good \\
\hline 2 & Construction & $91,42 \%$ & Very Good \\
\hline 3 & Language & $100 \%$ & Very Good \\
\hline & Average & $97,14 \%$ & Very Good \\
\hline
\end{tabular}

TABLE IV, Cont.

\begin{tabular}{|c|c|c|c|}
\hline \multicolumn{3}{|c|}{ Readability } \\
\hline 1 & General Layout & $93,33 \%$ & Very Good \\
\hline 2 & $\begin{array}{c}\text { Unsimilarity and } \\
\text { Code of Ethics }\end{array}$ & $75 \%$ & Good \\
\hline 3 & Suitability language & $85 \%$ & Very Good \\
\hline 4 & Clearity & $100 \%$ & Very Good \\
\hline \multicolumn{2}{|c|}{ Rata-rata } & $88.33 \%$ & Very Good \\
\hline
\end{tabular}

The validation result by experts showed that the module has already been in accordance with the objectives because it was qualified "very good" according to the content experts by $87.94 \%$, construct experts by $93.37 \%$, readability experts by $88.33 \%$, and evaluation experts by $97.14 \%$. Nevertheless, it still needed some improvement in accordance with the suggestions given by the experts through module revisions.

The assessment percentage of the validation result by experts in Table 2 showed that the module characteristics, material validity, evaluation questions, and language used in Generative Learning-based module of Respiratory System had been already in line with the targets, because the four validation results were qualified "very good" with the validation result of $>83 \%$. The validation result by expert showed that the module product is feasible to continued on limited field testing.

Furthermore, the module product will be tested on small scale involving two education practitioners and ten students in XI IPA. The objective of this initial field trial was to collect the information that can be used as a material to improve the product on the next revisions The suggestion and input given by the education practitioners and students were presented in Table 5.

TABLE V. THE MODULE EVALUATION BY THE PRACTICIONERS AND

\begin{tabular}{|c|c|c|c|c|}
\hline & & TUDENTS & & \\
\hline \multirow[t]{2}{*}{ No } & \multirow[t]{2}{*}{ Aspect } & \multicolumn{2}{|c|}{ Persentage (\%) } & \multirow[t]{2}{*}{ Categorize } \\
\hline & & Practicioner & Sudents & \\
\hline 1 & Content & $100 \%$ & $84 \%$ & Very Good \\
\hline 2 & Suitability & $97,5 \%$ & $90 \%$ & Very Good \\
\hline 3 & Benefit for learning & $100 \%$ & $94 \%$ & Very Good \\
\hline 4 & Layout & $98,75 \%$ & $89,5 \%$ & Very Good \\
\hline 5 & Readability & $97,14 \%$ & $87,13 \%$ & Very Good \\
\hline 6 & Generative learning & $89,99 \%$ & $89,99 \%$ & Very Good \\
\hline & Average & $97,10 \%$ & $89,10 \%$ & Very Good \\
\hline
\end{tabular}

The evaluation results by the education practitioners and students as the small group of users showed that the module has already been in line with the objectives that are being developed. Mostly, the education practitioners and students gave "very good" category in the evaluation with the evaluation result $>83 \%$, which was $97.23 \%$ and $89.10 \%$. The evaluation of Generative Learning-based module of Respiratory System by the practitioners and students showed that the content, material, presentation, language/readability of the module has already been qualified "very good", but it still needs improvement based on the suggestions (advice) by some practitioners and students through product revisions. Teachers explained that the module is good and able to explain the material of respiratory system, while the students said that the module is good enough and interesting because it contains pictures and colors so that it is not monotonous and it will be interesting to read.

The result of product revisions is Generative Learningbased module of Respiratory System and is ready to use 
because it has been validated by experts, evaluated by education practitioners so that it can be continued on operational field testing in order to test the effectiveness of the Generative Learning-based module of Respiratory System towards students' analytical thinking skill.

C. The Potency of Generative Learning-Based Module to Improve Students' Analytical Thinking Skill

Generative learning-based module has a set of systematical activities that accommodate thinking skill in learning through instruction and practice arranged specifically. In line with this statement, generative learningbased module of respiratory systems has activities that stimulate the process of students' thinking skills[12]. Those activities are the results of the integration of generative learning model syntax and the indicators of analytical thinking skills. Many students activity could empower students' thinking process. It could occur in active process when students built meaning system and understanding about the fact through their experiences and interactions in learning sources or with their friends[13]. In addition, the module characteristics are user-friendly. It eases students to learn using simple language and easy to understand[1]. Module is also presented communicatively. It was like there is interaction between teacher and students.

The activities on exploration stage was that the students were given the opportunity to utilize the five senses as much as possible to stimulate the students' curiousity which lead to the development of a high-level reasoning power. The students got the opportunity to build concepts by connecting the information obtained from daily life which had been previously owned. At this stage, giving opportunity for the students to build their own concepts can stimulate the realization of the first indicator of analytical thinking skill that is to interpret information and ideas. The focusing stage, the students thought of setting ideas in solving the problems and doing the experiment. At this stage, this leads students to argue or develop their own concepts. In line with Piaget's statement, that everyone is provided with the innate characteristics of curiosity and they keep trying to understand the world around them[7]. By doing so, the students had already performed the indicator of analytical thinking skill which is to identify similarity and difference of the reality and the information that was presented and to draw hypothesis.

The challenge stage, the students accepted the challenge of thinking in comparing opinions and expressed the superiority of each opinion with a scientific evidence. This exchange of opinions could improve understanding and provide opportunities to develop ideas so as to increase the students' opportunities to develop ideas[14]. This stage is the stage that stimulates analytical thinking skill on the indicator of proving previous hypothesis by elaborating the correlation among sentences or parts of a concept to draw conclusion. The concept application stage, the students were given the opportunities to solve the problems by applying the concepts which had been obtained. This stage helped students to empower their analytical thinking skill on the indicator of interpreting information and ideas, and elaborating the correlation of sentences or parts of a concept to draw conclusion.

The syntax of the model could encourage the students to empower the higher thinking processes so that the
Generative Learning model-integrated respiratory system module had the potential to enable training the analytical thinking skills. The analytical thinking skills can be improved by drilling the students to do analysis processes towards a problem in a learning[15]. Because, it is important for students to optimize their analytical thinking skills to solve their problems and daily problems in a long-term life[16].

\section{CONLUSSIONS}

The characteristics of the generative learning-based module of Respiratory System are integrated with generative learning model syntax on the students worksheets. The conclusion of this validation result shows that the module is categorized "very good" so it is feasible to use and continued on the phase of operational test. Generative learning-based module of Respiratory System has the potency to empower the analytical thinking skill through the activities.

\section{Acknowledgment}

We are grateful to validators, teachers, and students eleventh grade of public high schools in the kotabumi Regency, Indonesia for participating in the project.

\section{References}

[1] Daryanto 2013 Menyusun Modul Bahan Ajar Untuk Persiapan Guru Dalam. Mengajar (Yogyakarta: Gava Media)

[2] Wena Made 2009 Strategi Pembelajaran Inovastif Kontemporer (Jakarta: Bumi Aksara)

[3] Facione P a. 2011 Critical Thinking: What It Is and Why It Counts Insight Assess. 1-28

[4] Ivan E, Sudarisman S and Baskoro P A 2013 Salah satu model pembelajaran yang diharapkan dapat mengatasi permasalahan di atas adalah generative learning model. Generative Learning Model ( GLM ) merupakan suatu model pembelajaran yang mendorong mahasiswa untuk berpikir . Esensi GLM bertumpu pada p Sebel. Maret Univ.

[5] Diraksa T and Terntachatipong P 2009 THE DEVELOPMENT OF GRADE 10 STUDENTS ' ANALYTICAL THINKING ABILITY AND LEARNING ACHIEVEMENT ABOUT HEREDITY BY USING CONSTRUCTIVIST THEORY TEACHING STRATEGIES BASED ON UNDERHILL APPROACH Tianthong Diraksa Phairoth Termtachatipong The research aimed to deve 2002 1-8

[6] Siregar E and Nara H 2010 Teori Belajar dan Pembelajaran (Bogor: Ghalia Indonesia)

[7] Anderson R 1992 Some Interrelationships between Constructivist Motiels of Learning and Current Neurobiological Theory, with Implications for Science Education 29 1037-58

[8] Novak J D and Cañas A J 2008 The Theory Underlying Concept Maps and How to Construct and Use Them 1 Florida Inst. Hum. Mach. Cogn. 136

[9] Ritchie D and Volkl C 2000 Effectiveness of Two Generative Learning Strategies in the Science Classroom 100

[10] Wittrock M C 1991 Generative Teaching of 


\section{Comprehension 92}

[11] Sugiyono 2011 Metode Penelitian Kuantitatif Kualitatif dan $R \& D$ (Bandung: CV Alfabeta)

[12] Maknun J 2015 The Implementation of Generative Learning Model on Physics Lesson to Increase Mastery Concepts and Generic Science Skills of Vocational Students 3 742-8

[13] Robbins J K 2011 Problem Solving, Reasoning, and Analytical Thinking in a Classroom Environment 12

[14] Purwo W 2016 Makalah Pendamping Peran Pendidik dan Ilmuwan dalam Menghadapi MEA ISSN : 2527-6670 Pengembangan Modul Fisika Berbasis Generative Learning Untuk Meningkatkan Kemampuan Berpikir Kritis Siswa 66-71

[15] Duron R, Limbach B and Waugh W 2006 Critical Thinking Framework For Any Discipline 17 160-6

[16] Schumacher C and Ifenthaler D 2018 Features students really expect from learning analytics Comput. Human Behav. 78 397-407 